5,000 ontries, covoring the poriod 1944-1960, when the quarterly bibliographies published by Cryogenics began to appear. The contents consist of five parts dealing with hydrogen and helium; non-metallic substances at low tomperatures; non-superconducting metals and alloys: and miscellaneous topies, respectively. The entries, which give the authors, title of paper and referenco, are arranged alphabetically under twenty-two headings within the five parts.

\section{Advanced Courses in Science and Technology}

DetaILs of short courses in science and technology available in the London area aro containod in two recent publications. One describes those being held at the Imperial College of Science and Technology, and includes many short part-time locture courses in a series of disciplines as well as a number of short fulltime courses in various aspects of chemical, electrical and mechanical engineering, zoology and applied entomology (Shorter Postgraduate Courses, Session 1961-62, Spring Term. Pp. 20. London: Imperial College of Science and Tochnology, 1961). The other bulletin has been issuod by the London and Homo Counties Regional Advisory Council for Tochnological Education and provides dotails of a wide rango of short, ad hoc courses to be held at senior technical colleges in and around London (Bulletin of Special Courses in Higher Technology, including Management Studies and Commerce, 1961-62. Part 2: Spring and Summer Terms. Pp. 88. London: London and Home Counties Regional Advisory Council for Technological Education, 1962). Most of these are held in the evenings. Thoy include advanced courses in management studios.

\section{Museum of Applied Arts and Sciences, Sydney}

AN interesting and original format marks the annual report for the year onded Docomber 31, 1961, of the Museum of Applied Arts and Sciences in Sydney (Pp. 24. Sydney: Musoum of Applied Arts and Sciences, 1961). Unfortunately, no progross has been made to draw up plans for a new wing and so relieve the excessive congestion which has concerned the Trustees since 1958 and before. Fortunately, there is an increase in the statutory endowment which, among other schemes, has enabled the Trustees to modernize progressively the three county museums at Broken Hill, Bathurst and Goulbum. It is also recorded with satisfaction that the famous models of the Australian pionecr in aviation, Lauronce Hargrave, have been returned to the people of Australia by the Deutsches Museum, Munich, Cormany. The Museum now holds all the existing examples of the works of Hargrave with the exception of four models still retained by the Deutsches Museum. Now exhibits include one to illustrate tho process of metal spraying and the spraying of plasters on motal surfaces, ariother to show the doveloprnont of aids to calculation from the early abacus to the present day, and also one on early microscopes.

\section{Mental Subnormality and Community Care}

THE background to the problems of community mental health services was described in a P.F.P. broadshoet, Community Mental Ilealth Services (seo Nature, 189, 717; 1961). Another broadsheot in tho three-year study programme, which is being finuneed by the Nuffield Provincial Hospitals Trust, provides a general review of the present situation with regard to mental subnormality (Planning, Vol. 27, No. 457 (December 11, 1961): Mental Subnormality and Com- munity Care. Pp. 317-344. London: Political and Economic Planning, 1961. 3s. 6d.). The broadsheet describes legal changes and the way they have affected the community mental health services, the epiderniology of subnormality, existing services for the subnormal, and the way in which recent advances in tho study of mental subnormality have opened up certain limited possibilities of prevention. These generally operate by means of either genetic counselling or the carly diagnosis of endocrine or motabolic abnormalitics which, if uncorrected, may lead to mental defect. Further research in the genetics and biochemistry of subnormality must be encouraged, but it would be over-optimistic to anticipate any but marginal advances in the ability to prevent or cure. There is, however, a good deal which can be done by epidemiological, psychological and social research to extend understanding of the problem, and to guide the development of services. Indications are given of tho type of research activities which could lead to practical action.

\section{Causes of Lung Cancer}

THE fourth Henderson Memorial Iecture at the University of Glasgow was delivored by Dr. J. W. Cook, vico-chancellor of the University of Exeter, who examined the relationship of tobacco smoke to lung cancer. Dr. Cook ranged widely in his address to examine any factors which might influonce lung cancer, as well as the statistical, epidemiological and chemical evidence indicating the link between tobacco smoko and lung cancer. Nowhere has the relationship between lung eancer and tobacco smoke been more convincingly argued, and although, as Dr. Cook indicated, confirmed smokers are unlikely to change their habits, his opinion that "the young who have never smoked should be discouraged from making a start" would find a widespread acceptance. The address has been publishod by the Royal Institute of Chemistry (Lecture Series 1961. No. 5: Tobacco Smoke and Lung Cancer. By Dr. J. W. Cook. Pp. 18. London: Royal Institute of Chemistry, 1961. 48.).

\section{Hazards of High Altitude}

THE problems which face an astronaut have been examined by Prof. H. L. Saha, Nilratan Sircar Medical College, Calcutta, who classifies them into fivo categories. The first includes problems related to the acceleratory forces acting on the human system. These accolatory forces act on the human body during rapid ascent to or rapid descent from high altitude and also during rapid change in the direction of flight. The second includes problems related to low barometric pressure at higher altitude. 'The higher the altitude the lower is the barometric pressure, and this may give rise to complications arising from the expansion of gases in tho body cavities. Indeed, if an avintor is exposed suddonly to low baromotric pressure, the gases in his stomach and lungs may expand to such an extent as to cause immediate death. At still higher altitudes, $63.000 \mathrm{ft}$., the blood and the body fluids begin to boil in tho same way as a beaker of water will boil when oxposed in an ovacuated chamber. 'The third problem of high altitude is anoxia, the defective oxygenation of the blood and tissues resulting primarily from diminishod barometric pressure at high altitude. The fourth problem is the ono associated with temperature changes at highor altitude. The fifth is the effect of ionizing radintions on the human body, particularly those of cosmic radiations at comparatively lower 